\title{
The Strategic Priorities of Development of Traditional Crafts of the Northern Indigenous Peoples
}

\author{
Lyubov L. Bogomolova \\ Ilya V. Mayakovskiy
}

Yugra State University Khanty-Mansiysk autonomous district - Yugra

Email: I_bogomolova@ugrasu.ru

Doi:10.5901/mjss.2015.v6n2p312

\section{Abstract}

The article deals with strategic priorities of development of the northern indigenous peoples and problems of development of new forms of business and business activity of traditional crafts as one of the reserves of diversification of sector-specific oil and gas producing areas. Contents of state support for development of traditional crafts of the northern indigenous peoples: the mechanism, methods and forms of state support and development of entrepreneurship on the basis of the organization of trading stations, as the legal form of the business development initiatives are revealed. The goal of the research is to study promising priority directions of development of traditional crafts of the northern indigenous peoples and to examine the problems of their development. Scientific research aims to study the development of new forms of entrepreneurship initiative traditional crafts of indigenous peoples on the basis of export-oriented economy of northern peoples The products of traditional crafts of the northern indigenous peoples (wild harvest: mushrooms, berries: cranberries, red bilberries, pine nuts, products of reindeer breeding, the skins of beasts, and others) have specific characteristics, in terms of ecology, health and business. These products are well demanded by the market and may well be in demand abroad. The priority directions in the development of export-oriented entrepreneurship and cooperation of wild plants are the Asian and the European markets where natural, organic products having useful properties and which are abundant in the territory of the district are highly valued.

Keywords: priorities, trading stations, traditional crafts of the North, the northern indigenous peoples, traditional business functions, state support

\section{Introduction}

Khanty-Mansiysk autonomous district is one of the main petroliferous region of Russia and one of the greatest oilproducing regions of the world, it refers to the regions suppliers of Russia and leads in a number of key economic indicators: oil, power generation, industrial production and natural gas production. Enterprises of autonomous region constitute a significant portion of the Russian economy: about $7.5 \%$ of industrial production and $15.1 \%$ of revenues of the state budget by their activities. The share of Yugra in Russian oil production for 2013 amounted to $48.8 \% .104$ oil and gas companies operate on the territory of the autonomous district. The share of the autonomous district in total volume of gas production in Russia is 5\%. In 2013255,1 million tons of oil was produced and 33.0 billion $\mathrm{m}^{3}$ of associated petroleum gas was extracted. Khanty-Mansiysk autonomous district is an export-oriented region and it falls to $95.6 \%$ share of exports, while the import share is $4.4 \%$ in total volume of foreign trade turnover. Out of all the export volume $99,4 \%$ is the crude oil. The import of goods and services increased by $8,4 \%$ for the last year. Khanty-Mansiysk autonomous district Yugra is sector-specific oil and gas producing region with the limited amount of major industries in the structure of the regional economy and well developed additional and ancillary industries. Diversification of the regional economy is a priority of the government bodies of the region.

\section{Research Methodology}

The importance of the study consists in increasing role of development of traditional crafts of the indigenous peoples of the North as a strategic priority in the development of the regional economy on the basis of state support in terms of diversification and import substitution.

In a research study used the following methods: informal (logical) methods of situational analysis and forecasting method of expert evaluations, comparisons and detailed methods of economic processes. In scientific research have 
been applied formal methods: the classical methods of economic analysis and traditional methods of economic statistics. There are no any research methodology, methods and Russian experience in the study of the russian problems and forms of entrepreneurship and entrepreneurial initiatives of traditional crafts of Indigenous Peoples of the North.

The northern indigenous peoples live mostly in rural localities, more than $10 \%$ of them keep traditional way of life in the territories of traditional nature use.

The traditional economic activities of indigenous peoples of the autonomous district include reindeer breeding, fishing, hunting, trapping, gathering, traditional crafts such as making national clothes, utensils, fishing gear, etc.

In terms of financial and economic crisis, the issues of socio-economic situation and development of the indigenous peoples of the North become topical. Fall of living standards of the most of indigenous peoples of the north areas, unemployment, increased competition in the labour market, inflation, geopolitical instability, the development of forms of fee paid education and training of the population, as well as the seasonality of fish production and gathering of wild herb, insufficient supply of tribal communities in products, materials, specific features of the location of the territories of traditional nature use (a significant distance from major north cities) make the Government of the Khanty-Mansiysk Autonomous district - Yugra to put a priority of the development of socio-economic development programmes and sustention of living standard of indigenous peoples, organization of new forms of entrepreneurial activity with the aim of increasing the competitiveness of their products . (Araslanov R.K, 2010)

The legal framework for the protection of rights and traditional mode of life of the indigenous peoples of the North has been created in the Russian Federation. Russia is a party to international treaties in this field. Measures of state support (in the form of incentives, subsidies, quotas on the use of biological resources) have also been legislated. Benefits for representatives of indigenous peoples of the North living in places of traditional residence and traditional economic activities and engaged in traditional economic activities, are provided by the Tax code of the Russian Federation, Forest code of the Russian Federation, Water code of the Russian Federation Land code of the Russian Federation (The concept of sustainable development of indigenous peoples of the North, Siberia and Far East of the Russian Federation, 2009)

There is state support for the development of traditional economic activities and entrepreneurship through the provision of grants, the development of reindeer breeding, harvesting and processing of wild plants, fishing, and hunting. The state support of development of traditional activities of the northern indigenous peoples is subsidization of the production of traditional economic branches, which contribute to the preservation of the volume of produced products and the increase in seasonal employment of the native born population.

Nowadays Khanty-Mansiysk autonomous district - Yugra has the programs to support indigenous people such as workshops, training, consultation, and exchange of methodological and practical experience in the creation of tourism products as the basis for innovative forms of business activities of the northern indigenous peoples as recently more attention is paid to the development of entrepreneurship of the tourism industry, with a focus on ethno-tourism.

Financial support is provided in the form of compensation of expenses for purchase of snowmobiles, boats and motors, power plants for entrepreneurs in tribal communities, the development of entrepreneurial initiatives in the traditional fields of activity.

The products of traditional crafts of the northern indigenous peoples (wild harvest: mushrooms, berries: cranberries, red bilberries, pine nuts, products of reindeer breeding, the skins of beasts, and others) have specific characteristics, in terms of ecology, health and business. These products are well demanded by the market and may well be in demand abroad. (Traditional nature use of KhMAo-Yugra, 2014)

Khanty-Mansiysk autonomous district - Yugra is sector-specific oil and gas producing region, whose economy is entirely dependent on oil production, and oil prices on the world market relatively. The issue of diversification of the economy of the region, the development of import-substituting sectors of the national economy and export-oriented regional production raised due to recent events and tense geopolitical situation.

Khanty-Mansiysk Autonomous district - Yugra has significant reserves of economic diversification through the development of traditional crafts, the advantage of which consists in the use of environmentally friendly and renewable raw materials. In addition, traditional crafts are a subject of interest to tourists, which is a motivation for the development of the tourist industry of the district. The development of the traditional sector will allow to solve problems of education, employment of indigenous peoples of the North, identity and culture.( Araslanov R.K., 2010)

Khanty-Mansiysk Autonomous district - Yugra has significant natural resource potential. Therefore the economy of KhMAO-Yugra can be based on the development of traditional crafts of the indigenous peoples of the North too. (Kurikov V.M., 2007)

Annually more than 60 thousand tons of berries: cranberries-19.5 tons, blueberry-10.6 thousand tons, cranberries32.1 tons, 40 tons of mushrooms grows in the Khanty-Mansiysk autonomous district- Yugra. There are 2114 tons of pine 
nuts that count about $70 \%$ of the reserves of the Ural federal district within our district. The priority directions in the development of export-oriented entrepreneurship and cooperation of wild plants are the Asian and the European markets where natural, organic products having useful properties and which are abundant in the territory of the district are highly valued. (Export Bulletin of Ugra, issue No. 2, 2014)

Currently the interest to the use of wild medicinal plants, berries and mushrooms is increasing in the pharmaceutical, food, cosmetic industry, there is also growing demand for organic food all over world. KhMAO-Yugra, as the carrier of vast reserves of ecologically friendly raw materials, may become one of the largest suppliers of such raw materials. (Analysis of the use of fish and wildlife resources of the Khanty-Mansiysk autonomous district-Yugra, 2006)

The territory of the autonomous district traditionally refers to the area of hunting, it is a home to almost all members of the hunting animals and birds common for the taiga zone of West Siberia: moose, wild reindeer, lynx, sable, marten, ermine, weasel, otter, mink, muskrat, hare, squirrel, red fox, badger, bear, wolf, wolverine, water fowl (geese, ducks) and upland fowl (capercaillie, black grouse, hazel grouse, willow grouse). (Kharamzin T.G., 2001) Today products of hunting are in great demand in foreign markets because of its uniqueness, environmental friendliness and limited sales.

The strategic aim of economy development in Khanty-Mansiysk autonomus districts to achieve high living standards and social well-being for the population as a whole and for the northern indigenous peoples in particular through the effective development of oil and gas sector and the other branches of economy, the formation of the necessary conditions for the modernization and innovative development of regional economy and providing the rapid development of human capital, social infrastructure development. (Resolution of the Government of the Khanty-Mansiysk autonomous district - Yugra, 2012)

The strategic priorities of social and economic development of the northern indigenous peoples of KhantyMansiysk autonomus district- Yugra are determined on the base of the developed and established programme of development, the main direction of which is to develop entrepreneurship of the northern indigenous peoples by organizing trading stations and export-oriented development of the traditional crafts. (The concept of sustainable development of indigenous peoples of the North of Khanty-Mansiysk autonomous district - Yugra, 2011)

The basic institutions of self-organization of indigenous peoples of the North in the traditional sector of the KhantyMansiysk Autonomous Okrug-Yugra, in accordance with the Law On indigenous peoples in Khanty-Mansiysk Autonomous district are communities (family, tribal and territorial neighbourhood). (The Law On communities of indigenous peoples in Khanty-Mansiysk Autonomous district, 2001)

In contrast to the known forms of entrepreneurship, communities are non-profit organizations and their main purpose is not the profit.

One of the most effective organizational forms of entrepreneurship and entrepreneurial skills, well-proven in the recent past is the creation of trading stations in the north development of natural resources.

The trading station according to the law is the legal entities and individual entrepreneurs engaged in activities in places of traditional residence of the traditional economic activities of indigenous peoples (Khanty, Mansi and Nenets). (. The Law of Khanty-Mansyisk autonomous district No. 141-0z "On trading stations in Khanty-Mansiysk autonomous district - Yugra, 2010) The law about trading stations.

According to the decree of the Government of the Russian Federation dated from 07 March 2000 No. 198 of the Concept of state support of economic and social development of north regions trading stations are supply and sales structures of the rural economy, reproduced in the residence of the indigenous peoples of the North in order to ensure the supply of food and essential commodities in exchange for products.

The trading station is considered as organizational and technological structure, designed to ensure the marketability of traditional activities through the implementation of commodity operations. In particular, the organization of exchange of fish to fishing gear, equipment and other goods necessary for the life of the indigenous peoples of KhMAOYugra. In addition, the relationship of trading stations and suppliers of products do not exclude cash payments. (Kurikov V.M., 2007)

Trading stations will help to solve the problems of procurement, storage, processing, transportation and sales of products of traditional crafts of the north.

\section{The Main Part of Research}

The main problem, which will help to solve the creation of trading stations, is preservation of the deer population. Reindeer husbandry is an important sector for the traditional lifestyle of indigenous peoples, the economic component of their entrepreneurship. The main activities of the trading stations of the northern indigenous peoples are

- organization of reception, processing, storage, transportation and sales of traditional economic activities of 
indigenous peoples (including creation of trading and procurement databases);

- provision (including the organization of delivery and implementation) of indigenous peoples with food and nonfood goods, logistical means, necessary for the implementation of traditional economic activities and social services in accordance with the recommended minimum list of goods services. (Bogomolova L.L., 2012)

Trading stations can assist indigenous peoples in addressing transport issues, carrying out veterinary activities, cultural events, medical examinations, information and communication support, and other assistance oriented to improving the living conditions of the northern indigenous peoples.

Export-oriented development of traditional industries and crafts of the northern indigenous peoples in the conditions of market system plays a key role in the process of economic growth of the Khanty-Mansiysk autonomous district- Yugra because it reflects the economic strategy of the state, which consists in improving the well-being of the northern indigenous peoples, strengthening the security of their existence, the expansion of their rights and opportunities, upgrading of social status and sustainable development of the area of traditional natural resource use.

Export-oriented development of entrepreneurship in traditional crafts of the northern indigenous peoples is the most important factor putting the economic potential of the traditional residence of indigenous peoples and investment processes in accordance with the selected development priorities of the region and is the main source of development of traditional crafts and traditional industries of Khanty-Mansiysk autonomous district- Yugra. (. Export Bulletin of Ugra, issue No. 3, 2014) However, export-oriented development of traditional industries will depend on commercial criteria, such as gaining the profit maximization from the investment and maximum return on investment with minimum costs on production purposes, in the existing system of management of business processes in the region while minimizing risk and sales period.

This leads to the fact that in the field of conservation of natural native residence of the northern indigenous peoples, scientifically grounded approach of commercialization of traditional crafts, the activities of which are aimed at the preservation of northern natural resources, sustainable development of traditional residence and that are less focused on sales impact cannot always be realized.

Along with that, currently the problem of the forms and methods by which you can track faces when commercial interest in traditional crafts of the northern indigenous peoples can become harmful to the environment is not solved. All these above-mentioned circumstances hinder the successful and speedy implementation of the transition of the traditional crafts of the North to export-oriented direction. In our opinion, a more detailed study of all aspects of exportoriented entrepreneurship of development of traditional crafts and, first of all, the legal issues of export, the environmental impact of the export production of traditional crafts, issues of environmental protection and many other aspects is required.

It is necessary to develop science-based and proven methods and techniques of gathering wild-growing herb, fishing, particularly valuable species, i.e. the standard approach, as well as the other sectors of the economy, the modernization of traditional fields of natural resources use. Approbation of such scientific methods at the level of the autonomous region would allow improving first, the quality of export-oriented products and secondly to develop forms and methods of export-oriented entrepreneurship that is very important for making appropriate strategic decisions to ensure socio-economic development of the northern indigenous peoples and positive results for other regions.

It is possible to consider the introduction of an enterprise initiative in a traditional economy of the northern people and especially in trade and hunting, fish, reindeer-breeding, arts and crafts, collecting wild plants, etc. as a basis of increase of their efficiency. Production of these branches is in special demand, the prices of their realization are rather high, expenses, concerning other branches are low and make 20 - 35\% in the price structure.

Today tribal communities of the northern indigenous peoples run business, but it is insignificant. Small business isn't connected directly with this or that form of ownership and a housekeeping form. It is possible to adapt to any of forms of ownership, i.e. it can be carried out and in the state form, and in the form of a cooperative farm, family, and individual and in the form of the mixed society and such organizational forms as trading stations. Therefore forms of the organization of business of indigenous peoples can be carried to forms of small business with all corresponding purposes, tasks and the principles of formation of small enterprises. In our opinion the problem is how to increase active involvement of indigenous peoples in business and business activity. (Bogomolova L.L., 2012)

Now the population of the northern indigenous peoples is 30894 people in Khanty-Mansiysk autonomous district Yugra. The northern indigenous peoples (69\%) mainly live in the rural areas, over three thousand people have a traditional way of life in borders of territories of traditional environmental management. (Mayakovskiy I.V., 2014)

Places of traditional accommodation of indigenous peoples are in remote districts, where infrastructure is poorly developed. Trade is rather risky business there, income of local population is unstable as results of hunting and other traditional crafts mainly depend on natural and other external factors. Besides, realization of production of traditional 
crafts of indigenous peoples isn't developed in these territories. Therefore development of business and enterprise abilities of indigenous peoples will help to solve problems of increase of efficiency of economic activity of traditional crafts, providing the guaranteed mechanism of sale of production of traditional managing of indigenous peoples and by that employment assistance, and also guarantees of providing with essentials, including food, and also social services. Problems of development of business are realized also in relation to the persons who do not belong to the indigenous peoples, but constantly live in places of their residence. All of this will increase quality of life of the population as a whole in Yugra.

\section{Discussion}

The purpose of formation of trading stations is assistance to improvement of quality of life of the population in places of traditional residence.

Problems of formation of trading stations are:

1) development of system of preparation, storage, processing, transportation and production sale, made by the indigenous peoples at implementation of types of traditional economic activity by them,

2) assistance with employment for indigenous peoples;

3) providing the indigenous with essentials, including food, and also with the social and material means necessary for implementation of types of traditional economic activity;

4) increase of economic efficiency of traditional economic activity of the indigenous peoples, including by implementation of the modern technologies in processing of production of traditional economic activity.( Bogomolova L.L., 2012)

One of the most effective organizational forms of development of business and enterprise abilities, is the creation of trading stations in the conditions of northern development of natural resources. Trading stations will help to solve problems of preparation, storage, processing, transportation and sale of production of traditional crafts of the North. (The Law of Khanty-Mansyisk autonomous district No. 141-oz "On trading stations in Khanty-Mansiysk autonomous district Yugra", 2010)

The second problem, which will be solved with the help of creation of trading stations, is a preservation of a livestock of deer. Reindeer breeding is the important branch for preservation of traditional way of life of indigenous peoples, it is an economic component of their business.

The third important problem is the personnel potential of traditional crafts of the North. There is no flow of young shots, there is a few young people who want to live in field conditions without elementary conveniences. There is a lowered level of vaccination of infectious diseases of animals, and veterinary and zootechnical assistance is not at the proper level. There isn't selection work as it is necessary to solve a number of problems in the branch.

The trading station is a legal entity, the individual entrepreneur who is carrying out kinds of activity in places of traditional accommodation of traditional economic activity of the indigenous peoples (the Khanty, Mansi and Nenets).

\section{Concluding Remarks}

Trading stations can assist indigenous peoples in addressing transport issues, carrying out veterinary activities, cultural events, medical examinations, information and communication support, and other assistance oriented to improving the living conditions of the northern indigenous peoples and in our opinion it will help to develop business and business activity of traditional crafts of the northern indigenous peoples.

The modern system of state support for the traditional crafts of the indigenous peoples of the North as the strategic priorities of the diversification of the regional economy of sector-specific regions meets the prerequisites laid in the Concept of sustainable development of indigenous peoples of the North, Siberia and Far East of the Russian Federation. allow:

Balanced development of traditional crafts of the indigenous peoples of the North on the basis of state support will

To create conditions for sustainable development of indigenous peoples of the North on the basis of comprehensive development of the resource potential of traditional arts and crafts, spiritual and cultural development, improving education and training level;

To develop traditional economic way of life of indigenous peoples of the North on the basis of increasing government support and the comprehensive development of economic structures in the areas of traditional nature management in maintaining the ecological balance; 
To improve the quality of life of indigenous peoples of the North, to create a life support system and social conditions that meet the satisfaction of their vital needs; (The concept of sustainable development of indigenous peoples of the North of Khanty-Mansiysk autonomous district - Yugra, 2011)

To enhance investment and entrepreneurial activity, to restore trade, financial and economic relations and integration into the regional economy;

To increase production level and realization of products of traditional arts and crafts, popular in foreign markets; (Export Bulletin of Ugra, issue No. 3, 2014)

To increase the level of employment (job creation) of indigenous peoples of the North by engaging of traditional arts and crafts in the sphere of production

8. To develop export-oriented focus of the traditional crafts of the indigenous peoples of the North; (Export Bulletin of Ugra, 2014)

9. To ensure the development of a network of trading stations in the traditional residence of indigenous peoples of the North. (The Law of Khanty-Mansyisk autonomous district No. 141-oz "On trading stations in KhantyMansiysk autonomous district - Yugra" from September 20, 2010)

\section{References}

The Law On communities of indigenous peoples in Khanty-Mansiysk Autonomous district from November 19 (2001)

The Law of Khanty-Mansyisk autonomous district No. 141-oz "On trading stations in Khanty-Mansiysk autonomous district - Yugra" from September 20 (2010)

The concept of sustainable development of indigenous peoples of the North, Siberia and Far East of the Russian Federation from February 4, 2009 No. 132-r.

The concept of sustainable development of indigenous peoples of the North of Khanty-Mansiysk autonomous district - Yugra / The Government of the Khanty-Mansiysk autonomous district - Yugra - (2011)

Resolution of the Government of the Khanty-Mansiysk autonomous district - Yugra, from October 19 (2010) No. 266-p of the Target program "Socio-economic development of the indigenous peoples of the Khanty-Mansiysk autonomous district - Yugra" in 20112013.

Resolution of the Government of the Khanty-Mansiysk autonomous district - Yugra, from October 13, 2012 No. 615rp "On forecast of socio-economic development of the Khanty-Mansiysk autonomous district - Yugra for 2013 and 2014-2015 planning period.

Analysis of the use of fish and wildlife resources of the Khanty-Mansiysk autonomous district-Yugra (2006), The Government of the Khanty-Mansiysk autonomous district - Yugra, The Control on the use of fish and wildlife resources. - Khanty-Mansiysk

Araslanov R.K. (2010) The problems of traditional crafts of the indigenous peoples of the North, Economist. 2010. No.7. Pp. 68-78

Araslanov R.K. (2010) Economic evaluation of traditional trades of numerically small indigenous peoples of the North of KhantyMansiysk autonomous district - Yugra, Problems of modern Economics. - 2010. - No. 4. Pp. 51-55

Bogomolova L.L. (2012) Forms of business organization in the northern territories, Monthly theoretical and scientific-practical magazine APK: Regions of Russia, №. 11. 2012. Pp. 73.

Bogomolova L.L. (2012) Problems of business entrepreneurship development of the traditional crafts of the indigenous peoples of the North, Conference proceedings SWorld "Modern problems and ways of their solution in science, transport, production and education 2012". 4th Edition. Vol. 30 - Odessa: KUPRIENKO, 2012 - 96 Pp.

Kurikov V.M. (2007)Fundamentals of life of the peoples of the North: Textbook, Under the editorship of the Doctor of sociological science N.G. Khayrullina, Doctor of economic science L.L. Tonysheva. - Tyumen: (TSOGU), 2007. - 302 Pp.

Kharamzin T.G.(2001) Economy of traditional natural management of indigenous peoples of the North - Khanty-Mansiysk, 2001. - 294 p.

Mayakovskiy I.V. (2014) An analysis of the legal framework and the current state of the economy of the traditional crafts of the indigenous peoples of the North Magazine "Economics and entrepreneurship", No. 10 (51) 2014, Moscow, 2014.

Export Bulletin of Ugra, issue No. 2 (2014) Information publication of the export promotion center of Yugra, Khanty-Mansiysk, 2014. Export Bulletin of Ugra, issue No. 3 (2014 Information publication of the export promotion center of Yugra, Khanty-Mansiysk, 2014.

Traditional nature use of KhMAo-Yugra. (2014) Available at: http:www.admhmao.ru/obsved/index.htm (accessed 04 October 2014).

Official website of the government of the Khanty-Mansiysk autonomous district - Yugra. (2014) Available at:http. www.admhmao.ru/ people/frame.htm (accessed 06.10.2014). 